\title{
Roles and Responsibilities Analysis of Substitution Notary Before Leaving Period
}

\author{
Andi Deny Zulkifli Nur ${ }^{*}$ and Achmad Sulchan**) \\ ${ }^{*}$ Master of Notary Law Student, Faculty of Law, Universitas Islam Sultan Agung email : \\ andideny08@gmail.com \\ ${ }^{* *}$ Faculty of Law, Universitas Islam Sultan Agung
}

\begin{abstract}
This research aims: 1) To find out the legal status of a substitution notary related to the notary who was replaced by a death before the leave ends. 2) Also to understand the administrative settlement mechanism for the Substitution notary Protocol related to the replaced Notary Public before the leave period ends. The research method used is Normative and Descriptive in nature which is supported by primary data and also references to books and related laws in the case of Substitute Notaries. Normative legal research is based on the logic of legal science from the normative side. It is descriptive in nature to present a complete picture of a problem and be described clearly. Based on the research, it is concluded that: In Article 35 paragraph 3 UUJN-P, namely that if the notary dies while on leave, then the duties of his office will be carried out by a substitution notary as a Notary's Temporary Officer no later than 30 (thirty) days from the date of the Notary's death. The administrative settlement mechanism for the Substitution notary Protocol, namely as a Notary Temporary Officer, has expired his term of office. The Regional Supervisory Council, then within 14 (fourteen) days from the end of the term of office of the Temporary Notary Officer, it is required to appoint a Notary as the recipient of the Notary protocol. Pursuant to Article 35 paragraph (4) UUJN-P that the Substitution notary Public as Temporary Officer of Notary Public has a period of submission of the Notary Public Protocol and the Substitution notary Public is no longer than 60 days from the death of the Notary Public.
\end{abstract}

Keywords: Responsibility, Substitution notary; Notary Protocol; leave period

\section{Introduction}

Notary comes from the word notarius, namely people who carried out writing in Roman times. In the fifth and sixth centuries the designation notarius, the compound notarii, was given to the author or the personal secretary of the king. ${ }^{1}$

Notary as a public official who is authorized by law who holds the position as a trust, the notary is a party who plays an important role ${ }^{2}$ in the effort to create a quality authentic deed, meaning that its power as evidence is recognized by law. ${ }^{3}$

Notary position in its presence or presence is desired by legal regulations with the

\footnotetext{
1 Nico. (2003). Tanggung Jawab Notaris Selaku Pejabat Umum. Yogyakarta: Centre for Documentation and Studies of Business Law (CDSBL). p. 31

2 Adigita, Monicha R., Ma'ruf, Umar., \& Witasari, Aryani. (2019). The Role and Protection of Laws to Notary Related To the Dispute That Made Between the Parties. JURNAL AKTA: Vol. 6, No. 4, 783-788. Retrieved from http://jurnal.unissula.ac.id/index.php/akta/article/view/7631

3 Flora, Henny saida. (2012). Tanggung Jawab Notaris Pengganti Dalam Pembuatan Akta. Kanun Jurnal Ilmu Hukum No. 57
} 
intention of helping and serving people who need authentic written evidence regarding circumstances, events or legal actions. ${ }^{4}$ Based on Act No. 2 of 2014, amendments to Act No. 30 of 2004 concerning the Position of Notary Public (UUJN) it is stated that Notaries are public officials who are authorized to make authentic deeds and have other powers as referred to in this law or based on law other invite. Most of the people in carrying out their activities are related to the law and need legal services, namely a notary. Notaries in the community are already familiar, especially in big cities like Yogyakarta, Jakarta, Surabaya and so on.

Notary is a position title for someone who has received legal education who is licensed by the government to do legal things, especially as an authentic proof of the deed he makes. Notary is a public official who has a big duty and responsibility in carrying out his position to work professionally in society regardless of any angle, therefore the task of a notary in serving the community is not limited by time and must be able to work anytime as long as the community needs legal services. When a Notary who is sick or is about to leave for Umrah (Small Pilgrim) or who is temporarily unable to carry out his duties.

When the notary leave can be granted if a Notary has carried out his / her position for 2 years and if it is less than 2 years, the Notary cannot take his leave. Applications for leave can be submitted one month before the date the leave begins and for submission of applications depending on the length of time of leave of each notary as stated in Article 27 paragraph (1) and (2) of Act No. 30 of 2004 concerning Notary Position, hereinafter referred to as UUJN, namely:

a. The notary submits a written request for leave accompanied by a proposal for the appointment of a replacement notary.

b. Application for leave as referred to in paragraph (1) shall be submitted to the competent official, namely:

1) Regional Supervisory Council in case the leave period is not more than 6 months.

2) Regional Supervisory Council in case the leave period is more than 6 months to 1 year.

3) Central Supervisory Council in case the leave period is more than 1 year.

In submitting an application for leave, a Notary Public must follow the recommendation for the appointment of a Substitution notary Public to replace and carry out his duties, in accordance with the character of the Notary Public, which must be continuous as long as the Notary is still in office. The notary concerned determines the period of time for his leave and is obliged to appoint a replacement notary. 2 Notaries in appointing a replacement notary are usually only employees who have worked as well as interns for a long time and are deemed capable of replacing them based on the notary's own assessment.

A Notary Public and Substitution notary Public in carrying out their duties has the obligation to educate every person who comes to the office to pour what the tappers

\footnotetext{
${ }^{4}$ Adjie, Habib. (2008). Hukum Notaris Indonesia Tafsir Tematik Terhadap UU No. 30 Tahun 2004 Tentang Jabatan Notaris. Bandung: Rafika Aditama. p. 14
} 
want into a deed, therefore when a Notary wants to take leave, he must appoint a Substitution notary to replace him so that the public can still carry out his legal actions. A Substitution notary as stated in Article 1 paragraph (3) UUJN-P is a person who is temporarily appointed as a Notary to replace a Notary who is on leave, is sick, or temporarily unable to carry out his position as a Notary. The requirement to be appointed as a substitution notary as in Article 33 paragraph (1) UUJN-P is a citizen of Indonesia who has a law degree and has worked as an employee of a notary office for at least 2 (two) consecutive years.

The added value of a profession is the degree to which a professional is able to resist the temptation to deviate so much faith. The foundation in the form of morality is imperative to build and notaries, as a top group, have a big share in the wider community in building morality. ${ }^{5}$

\section{Research Methods}

The research method used is Normative and Descriptive in nature which is supported by primary data and references from books related to the author's title and the Law of Notary Position and the Law which is also related to the title of the Responsibility of a Substitution notary concerning a Notary who is replaced by a deceased world before the leave ends.

Normative legal research is based on the logic of legal science from the normative side. Descriptive in nature to present a complete picture of a problem and be clearly described in the research results. This research has a starting point of analysis of laws and regulations related to the Responsibilities of the Substitution notary Public in the event that the replaced Notary dies before the leave ends.

\section{Results and Discussion}

\subsection{Role and responsibilities of the substitution notary public in the event that the} replaced notary dies before the leaving period

According to GHS Lumban Tobing in his book on Notary Position Regulations, the main authority of a notary is to make authentic deeds. The authenticity of a notary deed derives from Article 1 of the Notary Position Regulation where the Notary is made a "general official", so that the deed made by a notary because of his position has the character of an authentic deed. ${ }^{6}$

Article 1 point of Act No. 30 of 2004 jo. Act No. 2 of 2014 states that the main task of a notary is to make authentic deeds. As for the actual deed according to Article 11868 of the Civil Code is a deed which is in the form determined by law, is made by or in front of public officials who are in power for it at the place where the deed was made. This means that the Notary, because of the law, is given the authority to create absolute means of proof, in the sense that what is stated in the authentic deed is in the point is

\footnotetext{
5 Anshori, Abdul Ghofur. (2009). Lembaga Kenotariatan Indonesia Perspetif Hukum dan Etika. Yogyakarta: UII Press. p.1

${ }^{6}$ Tobing, G.H.S. Lumban. (1983). Peraturan Jabatan Notaris. Jakarta: Erlangga. p. 48
} 
considered true. ${ }^{7}$

Notaries in carrying out their duties are not free from mistakes, both intentional and unintentional. If the mistake is made intentionally, then the deliberation can be punished under Article 84 and Article 85 of the Law on the Position of Notary Public, which stipulates that the Notary is responsible for his mistake if proven to be guilty, the Notary may be subject to civil sanctions, administrative, even if there is an intentional element in the material intention it can become a criminal element. For example, deliberate writing errors can be a criminal element and a Notary can be subject to criminal sanctions for placing false information and ethical sanctions can be imposed on the Notary if the Notary violates the notary's code of ethics. ${ }^{8}$

Substitution notary is a person who temporarily replaces a Notary who is on leave, is sick or temporarily unable / unable to carry out his / her duties as a Notary as stipulated in Article 1 paragraph 3 UUJN-P. This substitution notary is appointed by the Minister through the local Regional Office, in this study, especially Sleman Regency is in the Yogyakarta Special Region Regional Office. The requirements to become a substitution notary as stated in Article 33 UUJN-P are: Indonesian citizens who have a law degree and have worked as employees of the notary office for at least 2 (two) consecutive years. Then the Substitution notary Candidate must complete supporting documents, including:

a. Photocopy of the lowest degree of law degree legalized by the relevant university

b. Photocopy of Identity Card which is legalized by a Notary

c. Photocopy of birth certificate legalized by a Notary

d. Photocopy of Marriage Certificate for those who are already married and legalized by a Notary

e. Certificate of good behavior from the local police

f. Health certificate from a government doctor

g. The most recent color photo, size $3 \times 4=4$ (four) sheets

A Notary Public and Substitution notary Public in carrying out their duties has the obligation to educate every person who comes to the office to pour what the tappers want into a deed, therefore when a Notary wants to take leave, he must appoint a substitution notary to replace him so that the public still be able to carry out his legal actions. A Substitution notary as stated in Article 1 paragraph (3) UUJN-P is a person who is temporarily appointed as a Notary to replace a Notary who is on leave, is sick, or temporarily unable to carry out his position as a Notary.

3.2. Mechanism/order of administrative settlement of the substitution notary protocol in the case of the replaced notary public dies before leaving period

The Supervisory Council is an agency that has the authority and obligation to carry out guidance and supervision of Notaries. This Notary Supervisory Body is formed by the Minister in order to delegate its obligations to supervise as well as foster Notary Public

\footnotetext{
${ }^{7}$ Notodisoerjo, Soegondo. (1993). Hukum Notariat di Indonesia Suatu Penjelasan. Jakarta: PT. Raja Grafindo Persada. p. 8

${ }^{8}$ Harahap, Nuzuarlita Permata Sari. (2011). Pemanggilan Notaris Oleh Polri Berkaitan Dengan Akta Yang Dibuatnya. Medan: Pustaka Bangsa Press. p.235-236
} 
which includes behavior and implementation. Notary Position. In carrying out its duties, the agency is functionally divided into 3 hierarchical sections according to a division of administrative areas, namely:

a. Central Supervisory Council, supervision carried out at the central level which is established and domiciled in Jakarta and has the authority to grant leave permits with a leave period of more than 1 (one) year

b. The Regional Supervisory Council shall supervise at the regional level which is established and domiciled in the Provincial Capital and has the authority to grant leave permits for more than 6 (six) months to 1 year, inspects and decides on the decision of the Regional Supervisory Council which rejects leave proposed by Notary reporting. As well as supervising the district / city.

\section{Closing}

Article 35 paragraph (4) UUJN-P that "Substitution notary Public as Temporary Notary Public has a period of time to submit the Notary Public and Substitution notary Protocol is a maximum of 60 days from the death of the Notary Public", but in practice it is often not in accordance with the time limit given. due to several factors, one of which was the fact that the minimum number of deeds was so many, there were still some that had not been bound, and there was a lack of signatures of witnesses. The Substitution notary Public as Temporary Officer of the Notary will make an official report for the submission of the Notary's Protocol, then the Substitution notary will submit all Notary Protocols to the Notary Recipient of the Protocol. Then the minute of submission of the Notary Protocol is signed by the Substitution notary as the Temporary Officer of the Notary, the Notary who receives the Protocol and the Regional Supervisory Council.

\section{References}

Journal:

[1] Adigita, Monicha R., Ma'ruf, Umar., \& Witasari, Aryani. (2019). The Role and Protection of Laws to Notary Related To the Dispute That Made Between the Parties. JURNAL AKTA: Vol. 6, No. 4, 783-788. Retrieved from http://jurnal.unissula.ac.id/index.php/akta/article/view/7631

Books:

[1] Flora, Henny saida. (2012). Tanggung Jawab Notaris Pengganti Dalam Pembuatan Akta. Kanun Jurnal Ilmu Hukum No. 57

[2] Nico. (2003). Tanggung Jawab Notaris Selaku Pejabat Umum. Yogyakarta: Centre for Documentation and Studies of Business Law (CDSBL)

[3] Adjie, Habib. (2008). Hukum Notaris Indonesia Tafsir Tematik Terhadap UU No. 30 Tahun 2004 Tentang Jabatan Notaris. Bandung: Rafika Aditama

[4] Anshori, Abdul Ghofur. (2009). Lembaga Kenotariatan Indonesia Perspetif Hukum dan Etika. Yogyakarta: UII Press

[5] Tobing, G.H.S. Lumban. (1983). Peraturan Jabatan Notaris. Jakarta: Erlangga

[6] Notodisoerjo, Soegondo. (1993). Hukum Notariat di Indonesia Suatu Penjelasan. 
Jakarta: PT. Raja Grafindo Persada.

[7] Harahap, Nuzuarlita Permata Sari. (2011). Pemanggilan Notaris Oleh Polri Berkaitan Dengan Akta Yang Dibuatnya. Medan: Pustaka Bangsa Press. 